\section{Influence of Income For Mudharabah Results And Murabahah Margin Income on Profit Sharia Bank Business In Indonesia Period 2015-2019}

\author{
Falahuddin', Fuadi' ${ }^{2}$, Muammar Khaddafi ${ }^{3}$, Mohd.Heikal ${ }^{4}$, Damanhur Abbas ${ }^{5}$, Rico Nur \\ Ilham ${ }^{6}$ \\ 1,2,3,4,5,6 Faculty of Economic and Business Universitas Malikussaleh \\ falahuddin@unimal.ac.id, khaddafi@unimal.ac.id,mohdheikal@unimal.ac.id,damanhurabbas@gmail.com, \\ riconurilham@unimal.ac.id
}

\begin{abstract}
This study aims to analyze the effect of mudharabah revenue sharing and murabahah margin income on operating profit of Islamic banks in Indonesia for the 2015 - 2019 period. The data used in this study are data published by Islamic banks in Indonesia using data from 2015 to 2019 and obtained sample data of 48 data. In selecting the sample, the researcher used a purposive sampling technique, which is a sample selection method based on certain criteria to obtain a representative sample of the population. The results of this study indicate that the revenue sharing of mudharabah and Murabahah Margin income has a positive and significant effect on Operating Profit at Islamic Banks in Indonesia for the 2015-2019 period.
\end{abstract}

Coresponding Author:khaddafi@unimal.ac.id

Keywords: Mudharabah Revenue Sharing, Murabaha Margin Income and Business Length

\section{PRELIMINARY}

The emergence of the concept of Islamic banking based on the principle of profit sharing is considered more profitable than conventional banks which still apply the interest system. This is because Islamic banks are not charged with paying a fixed amount of profit sharing to customers, but the amount of profit sharing provided is in accordance with the amount of operating income obtained by Islamic banks so that the amount of profit sharing each month is not always the same while conventional banks are charged with paying interest which is a fixed amount. without taking into account the size of the bank's operating income, so that when a crisis occurs, conventional banks experience difficulties because there is a crisis, then credit payments by customers falter while the interest to be paid to customers is fixed.

In 2018 in January to be precise, the profit of Islamic banks was IDR 329 billion, down $12.03 \%$. The Financial Services Authority (OJK) noted that the profit of the Islamic banking industry as of January 2018 was IDR 329 billion. This value decreased by $12.03 \%$ compared to January 2017 which reached Rp 374 billion.

Meanwhile, in January 2017, Islamic commercial banks recorded a net profit of Rp 165 billion. Different things actually happened to the sharia business unit which recorded a net profit of IDR 297 billion in January 2018.

Based on the published financial reports, the decline in Panin Syariah's net profit also occurred in line with the decrease in revenue after distribution of profit sharing by $32 \%$, namely at the level of Rp. 140.04 billion from the previous year of Rp. 205.55 billion. As of September 2019, Bank Panin Syariah shares were held by Bank Panin at 53.7\%, Dubai Islamic Bank PJSC 38.25\% and the rest by public investors at $8.05 \%$. these funds.

Another product offered by Islamic banks is financing with the murabahah (buying and selling) scheme, which is most in demand by Islamic banks, because the risk they have is the least compared to other financing. Murabahah is an agreement to buy and sell an item at a price equal to, the cost of goods 
plus a mutually agreed profit with a deferred payment of 1 month to 1 year. The agreement also includes a lump sum payment method. Meanwhile, Al-Bai'u Bithaman Ajil, namely: Agreement to buy and sell an item at a price equal to the cost of goods plus a mutually agreed profit. This agreement also includes the payment period and the amount of installments.

Research conducted by Khan and Ahmed (2001) from IRTI (Islamic Research and Training Institute, IDB) states that Murabaha financing has the least risk. According to Syamsuddin (Ihsan 2011) there are several reasons murabahah contracts are very popular in Islamic banking operations; first, from the perspective of Islamic banks, that short-term investments are quite easy, the benefits derived from mark-ups can be determined and ensured, and avoid uncertainty and minimize risks in the profitsharing system; secondly, from the customer's perspective, murabaha does not allow Islamic banks to interfere in business management.

\section{Research purposes}

The purpose of this study is to obtain empirical evidence regarding:

1. To find out and analyze how much influence the revenue sharing of mudharabah results on operating profit in Islamic Banks in Indonesia for the 2015-2019 period.

2. To find out and analyze how much influence murabahah margin income has on operating profit at Islamic Banks in Indonesia for the 2015-2019 period.

\section{LITERATURE REVIEW}

\section{Operating profit}

Operating profit is income generated from business in a certain period then reduced by expenses used in generating income in a certain period (Harahap 2008). The other understanding says that what is meant by operating profit (profit) is a company's income which is formed from the difference in total revenue (revenue) minus expenses (expanses) in a certain period.

\section{Definition of Income Statement}

The income statement is a report that presents the results of the company's operations as outlined in the value of income and expenses (Sasongko 2016). An income statement is a report that shows the ability of a company or business entity to generate profits during a certain period. The income statement contains elements of nominal accounts, namely income accounts and expense accounts. With the income statement, it can be seen how far the company's development is, whether it is progressing in the sense of making a profit or experiencing bankruptcy in the sense of experiencing a loss.

\section{Definition of Income}

Revenue is the gross inflow of economic benefits during the current period that arises in the ordinary course of activities of an entity when the inflow is generated in additional capital, other than related to equity holder contributions (Muhammad 2014).

\section{Islamic Bank}

Islamic banks are financial institutions whose main business is to provide financing and other services in payment traffic and money circulation which operates in accordance with sharia principles (Heri 2003).

\section{Base Sharia Bank Operational Law}

Sharia commercial banks were first introduced in Indonesia in 1992. Based on Law no. 7 of 1992 concerning banking: "Banks can provide credit in exchange for or sharing the profits." and Government Regulation no. 72 of 1992: "Commercial banks or rural banks conducting business activities based on the principle of profit sharing." Islamic banking was more seriously developed in 1998. 


\section{Functions and Objectives of Islamic Banks}

In the Islamic accounting paradigm, Islamic banks have the following functions (Syafi'i 2001):

1. Investment Management

2. Investment

3. financial services

4. Social services

\section{Profit Sharing Concept}

The concept of profit sharing is very different from the concept of interest applied by the conventional economic system. The profit sharing concept contains the following (Neneng 2015):

1) Fund owners invest their funds through financial institutions that act as fund managers.

2) Managers manage these funds in a system known as the pool of funds system.

3) Both parties make an agreement (contract) which contains the scope of cooperation.

\section{Definition of Profit Sharing}

Profit sharing is the distribution of business results that have been carried out by the parties who entered into the agreement, namely the customer and the sharia bank. In the event that there are two parties entering into a business agreement, the results of the efforts made by both parties or one of the parties will be divided according to the portion of each party entering into the contract agreement. The distribution of operating results in Islamic banking is determined by using a ratio. The ratio is the percentage agreed by both parties in determining the profit sharing for the joint venture (Ismail 2011).

\section{Financing With Profit Sharing Principle}

Funding with the profit sharing principle is used for cooperative efforts aimed at obtaining goods and services at the same time, when the bank's profit rate is determined from the amount of business profits in accordance with the profit sharing principle. In profit sharing products, the profit sharing ratio is determined in advance. Banking products that are included in this group and are often used by Islamic banking are musyarakah and mudharabah.

\section{Mudharabah}

The definition of mudharabah in fiqh discourse is a contract that involves two groups, namely the owner of capital (investor) who entrusts his capital to the manager (mudharib) to be used in trading activities. Mudharib in this case contributes work, time, and manages his business in accordance with the provisions achieved in the contract, one of which is to achieve profit (profit) which is divided between the investor and mudharib based on a mutually agreed proportion (Abdullah 2008).

\section{The end of the mudharabah contract}

The duration of cooperation in mudharabah is uncertain and unlimited, but all parties have the right to determine the duration of the cooperation contract by notifying the other party.

1) In the event that the mudharabah is limited in time, then the mudharabah ends at the specified time.

2) One of the parties decided to resign

3) One of the parties dies or loses his mind

4) The fund manager does not carry out his mandate as a business manager to achieve the goals as stated in the contract

5) Capital no longer exists

\section{Pillars of Mudharabah}

The pillars of the mudharabah contract are:

1) Actors (capital owners and business implementers),

2) Mudharabah object (capital and work), 
3) Consent of both parties (ijab-qabul),

4) profit ratio,

5) Mudharabah technique in banking (Heri 2015).

\section{Revenue Sharing in Mudharabah Financing}

Profit sharing in the mudharabah transaction is the distribution of the results of the operations carried out by the mudharib on the capital provided by the shahibul maal. Profit sharing for this business cooperation is given in accordance with the ratio that has been stated in the mudharabah contract.

\section{Determination of Profit Sharing Ratio for Financing}

Islamic banks apply Profit Sharing Ratios to financing products based on natural umcertainty contracts (NUC), namely business contracts that do not provide certainty of income (return), both in terms of amount (amount) and timing (timing), such as mudharabah and musyarakah.

\section{Murabaha}

Murabahah is an agreement for a sale and purchase transaction between a bank as a seller and a customer as a buyer for goods at the agreed purchase price plus finance (margin) and with complete and transparent (honest) information between the two parties (Slamet 2009).

Murabaha is the sale and purchase of goods at the original price with an agreed additional profit. In murabaha, the seller must tell the price of the product he buys and determine a level of profit in addition (Syafi'i 2002).

\section{Murabahah Terms}

1) The seller informs the customer of the cost of capital.

2) The first contract must be valid in accordance with the stipulated pillars.

3) The contract must be free from usury.

4) The seller must explain to the buyer if there is a defect in the goods after purchase.

5) The seller must convey all matters relating to the purchase, for example if the purchase is made on debt.

\section{Pillars of Murabaha}

1) Seller

2) Buyer

3) Items for sale

4) Price and

5) Ijab-qabul

\section{Banking Technical}

In technical banking, Murabahah is done if the customer wants to buy the desired item, then the bank buys the item from the supplier. After the goods match, there is a murabaha contract with an agreed margin agreement.

\section{Framework}

Based on the theories that have been put forward above, it can be assumed that there is a relationship between mudharabah profit sharing and murabahah margin income to the company's profit.

\section{Hypothesis}

The hypothesis is a temporary answer to the formulation of the problem stated in the form of a statement. (Sugiono, 1999) The hypothesis proposed by the authors in this study are: 
$\mathrm{H} 1$ : There is a significant effect between the profit sharing of mudharabah on operating profit.

$\mathrm{H} 1$ : There is a significant effect between murabahah margin income to company profits.

$\mathrm{H} 3$ : There is a significant effect between the revenue sharing of mudharabah and murabaha margin income on operating profit

\section{RESEARCH METHODS \\ Population}

According to (Khaddafi et al., 2018) Population is a generalization area consisting of a group of people, events, or everything that has certain characteristics. The population in this study is Islamic banks in Indonesia.

\section{Sample}

According to (Khaddafi et al., 2018) The sample is part of the number and characteristics possessed by the population and carefully selected from the population. In selecting the sample, the researcher used a purposive sampling technique, which is a sample selection method based on certain criteria to obtain a representative sample of the population. The sample used in this study is Islamic Banks in Indonesia.

\section{Variable Operational Definition Dependent Variable (Y)}

According to (Khaddafi et al., 2018) states that the dependent variable or the dependent variable is a type of variable that is explained or influenced by the independent variable. The dependent variable in this study is net income (Y). Net profit is the income generated from the business in a certain period then reduced by the expenses used in generating income in a certain period.

\section{Independent Variable $(\mathbf{X})$}

According to (Khaddafi et al., 2018) Independent Variables or also called independent variables are types of variables that are seen as the cause of the emergence of the dependent variable which is thought to be the result. The independent variables in this study are Mudharabah profit sharing and Murabaha margin income.

- Classic assumption test

- Normality test

- Autocorrelation Test

- Heteroscedasticity Test

- Multicollinearity Test

\section{Data analysis method}

The analysis used is by using multiple linear regression analysis, this multiple regression analysis aims to determine the effect of the independent variables, namely Mudharabah revenue sharing and Murabahah margin income.

\section{Multiple Linear Regression Test}

Multiple linear regression is an extension of simple linear regression, which is adding the number of independent variables that were previously only one to two or more independent variables. 


\section{Hypothesis test \\ t test (Partial Significance Test}

The $t$ statistic test shows how far the influence of one independent variable or explanatory variable individually in explaining the dependent variable. The goal is to compare the mean of two sample groups that are not related to each other.

\section{F Test (Simultaneous Significance Test)}

The F statistical test basically shows whether all the independent variables included in the model have a joint or simultaneous effect on the dependent variable.

\section{RESULTS AND DISCUSSION \\ Research result \\ Descriptive Research Variables}

The research data consists of two independent variables, namely Mudharabah Revenue Sharing (X1) and Murabahah Margin Income (X2) and one dependent variant of Operating Profit (Y). to describe and test the effect of the independent variable and the dependent variable in this study, this section will present a description of each variable based on the data obtained.The output of SPSS 22.0 for Windows is as follows:

Table 1 Descriptive statistics

\section{Descriptive Statistics}

\begin{tabular}{|c|c|c|c|c|c|}
\hline & $\mathrm{N}$ & Minimum & Maximum & mean & $\begin{array}{l}\text { Std. } \\
\text { Deviation }\end{array}$ \\
\hline $\mathrm{X} 1$ & 60 & 3446.72 & 967768.00 & 239435.1927 & 27334739498 \\
\hline $\mathrm{X} 2$ & 60 & 15479.87 & 5747030.00 & 1271907.2172 & 1378594,42085 \\
\hline $\mathrm{y}$ & 60 & -311206.00 & 1399634.00 & 147065.1982 & 292771.82261 \\
\hline $\begin{array}{l}\text { Valid N } \\
\text { (listwis) }\end{array}$ & 60 & & & & \\
\hline
\end{tabular}

Based on table 1 above, the mudharabah revenue sharing variable has a minimum value of IDR 3,446.72 for the 2015-2019 period, the maximum value of IDR 967,768 for the 2015-2019 period, the mean value of 239,435.19 for the 2015-2019 period and the standard deviation of 273,347,395. . The murabahah margin income variable has a minimum value of IDR 15,479.87 for the 2015-2019 period, the maximum value of IDR 5,747,030 for the 2015-2019 period, the mean value of 1,271,907.21 for the 2015-2019 period and the standard deviation of 1,378,594.42 and the dependent variable operating profit has a minimum value of $-\mathrm{Rp} 311,206$ for the 2015-2019 period, the maximum value is $\mathrm{Rp} 1,399,634$ for the 2015-2019 period, the mean value is $147,065.2$ for the $2015-2019$ period and the standard deviation is $292,771.82$.

\section{Classic Assumption Results \\ Normality test}

Normality test is a test of the normality of the data distribution. In this study using the Kolmogrosov mirnov test with the following results: 
Table 2 Normality Test

One-Sample Kolmogorov-Smirnov Test

\begin{tabular}{|c|c|c|c|}
\hline & & & Unstandardized Residual \\
\hline \multicolumn{3}{|l|}{$\mathrm{N}$} & 53 \\
\hline \multirow{5}{*}{$\begin{array}{l}\text { Normal } \\
\text { Parameter } \\
\text {, b } \\
\text { Most } \\
\text { Extreme } \\
\text { Differencs }\end{array}$} & \multicolumn{2}{|l|}{ mean } & 0000000 \\
\hline & \multicolumn{2}{|c|}{ Std. Deviation } & 178.21461473 \\
\hline & \multicolumn{2}{|l|}{ Absolute } & .125 \\
\hline & \multicolumn{2}{|l|}{ Positive } & .125 \\
\hline & \multicolumn{2}{|l|}{ negative } & -.114 \\
\hline \multirow{2}{*}{\multicolumn{3}{|c|}{$\begin{array}{l}\text { Test Statistics } \\
\text { asymp. Sig. (2-tailed) }\end{array}$}} & .125 \\
\hline & & & $.037 \mathrm{c}$ \\
\hline \multirow{3}{*}{$\begin{array}{l}\text { Monte } \\
\text { Carlo Sig. } \\
\text { (2-tailed) }\end{array}$} & \multicolumn{2}{|l|}{ Sig. } & $.349 d$ \\
\hline & $9 \%$ & Lower Bound & .337 \\
\hline & $\begin{array}{l}\text { Confidene } \\
\text { Interval }\end{array}$ & Upper Bound & .361 \\
\hline
\end{tabular}

a. Test distribution is Normal.

b. Calculated from data.

c. Lilliefors Significance Correction.

d. Based on 10000 sampled tables with starting seed 926214481 .

The results of the normality test showed that all research variables had a significant value of more than 0.05 at (sig $>0.05$ ) which was 0.361 so it could be concluded that the research data were normally distributed.

\section{Multicollinearity Test}

Multicollinearity test was conducted to determine the magnitude of the intercorrelation between the independent variables in this study. If there is a correlation, then there is a multicollinearity problem that can be seen at the tolerance value and the VIP is below 10 then there is no multicollinearity. The results of the multicollinearity test for the regression model in this study are presented in the table below:

Table 3 Multicollinearity Test Results

\section{Coefficientsa}

\begin{tabular}{|c|c|c|}
\hline \multirow[b]{2}{*}{ Model } & \multicolumn{2}{|c|}{ Collinearity Statistics } \\
\hline & Tolerance & VIF \\
\hline 1 (Constant) & & \\
\hline $\mathrm{X} 1$ & .808 & 1,238 \\
\hline $\mathrm{X} 2$ & .808 & 1,238 \\
\hline
\end{tabular}

a. Dependent Variable: LB 


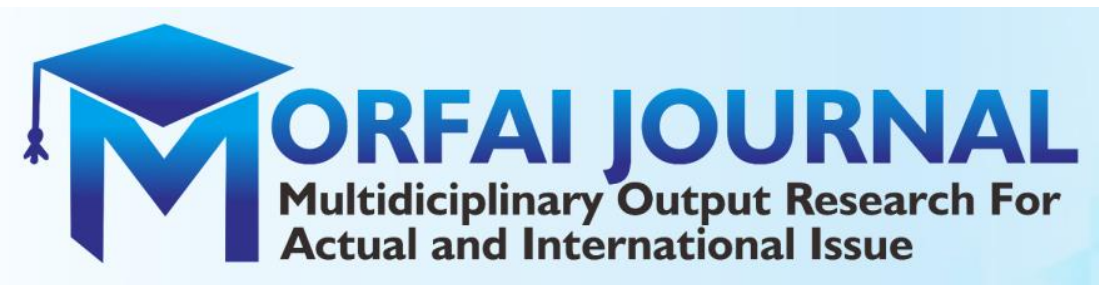

VOLUME I NO.1 (2021)

From the table above, it can be seen that all variables have tolerance values above 0.1 and VIF values below 10, so it can be concluded that the regression model in this study does not occur multicollinearity.

\section{Heterooxidity Test}

Heteroscedasticity test aims to test whether the regression model has an inequality of variance from the residuals of one observation to another observation. If the variance and residual from one observation to another observation remain, it is called homoscedasticity and if it is different it is called heteroscedasticity (Ghozali, 2016: 138).

The way to detect heteroscedasticity is to do the glejser test and look at the plot graph between the predicted value of the dependent variable and its residual and see whether there is a certain pattern on the scatter plot graph on the IBM SPSS Windows software version 22. The following table shows the results of the glejser test as follows:

Table 4 Heteroscedasticity Test Results

Coefficientsa

\begin{tabular}{|c|c|c|c|c|c|c|}
\hline \multirow[b]{2}{*}{ Model } & \multicolumn{2}{|c|}{ Unstandardized Coefficients } & \multirow{2}{*}{$\begin{array}{l}\text { Standardized Coefficients } \\
\text { Beta }\end{array}$} & \multirow[b]{2}{*}{$\mathrm{t}$} & \multirow[b]{2}{*}{ Sig. } & \\
\hline & $\mathrm{B}$ & Std. Error & & & & \\
\hline \multicolumn{2}{|c|}{1 Constant) } & 30014,669 & 32719,896 & & .917 & .636 \\
\hline \multicolumn{2}{|l|}{$\mathrm{X} 2$} & .067 & .018 & .479 & 3,694 & .046 \\
\hline
\end{tabular}

a. Dependent Variable: aBS_rES

Based on the output above, it is known that the significance value (Sig). For the profit sharing variable, it is 0.968 and for the margin income variable it is 0.468 . because the significance value of the two variables above is less than 0.05 , according to the basis for decision making in the glejser test, it can be concluded that there is a symptom of heteroscedasticity in the regression model. In a case like this, another alternative test is carried out to detect the presence or absence of heteroscedasticity symptoms using scatterplot images. The following is a graphic image of the scatter plot :

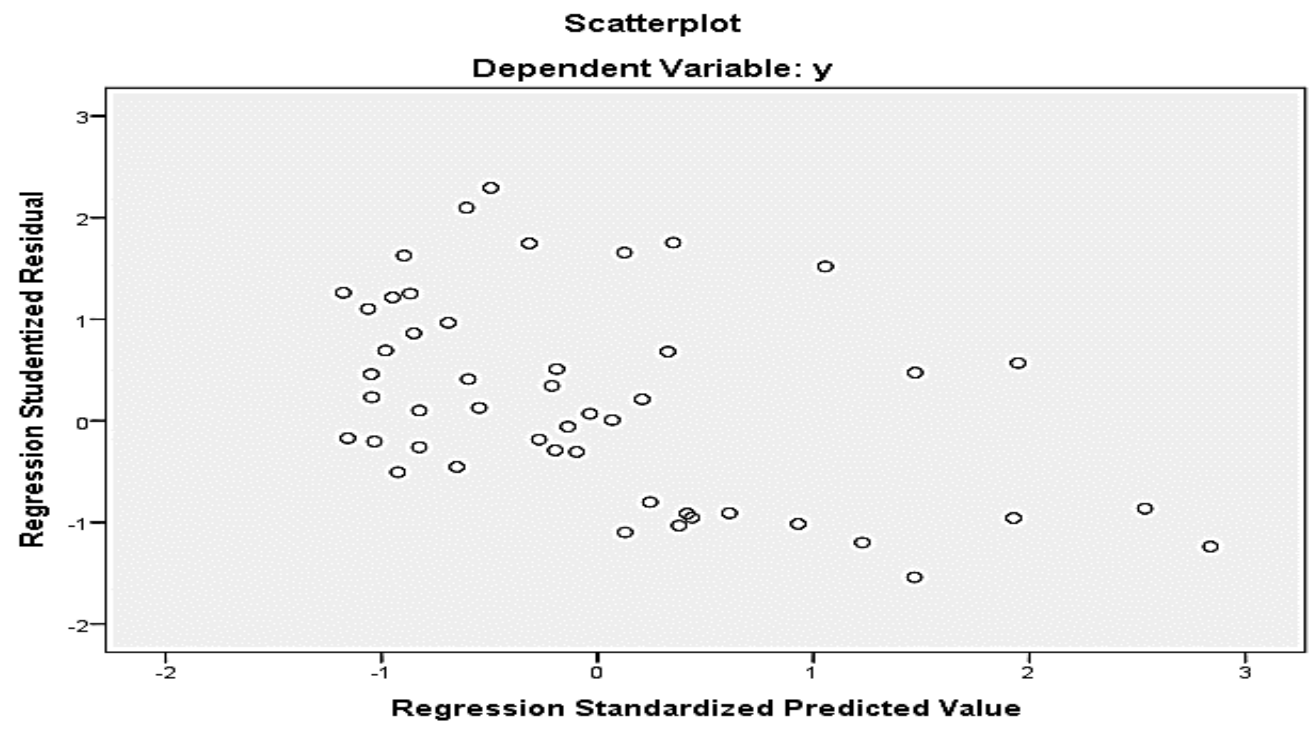

Figure 1 Scatterplot Graph 


\section{Autocorrelation Test}

Autocorrelation is a correlation that occurs between members of observations that are located in a row, which usually occurs in time series data. The test method used is the Durbin-Watson test (DW test) with the results shown in table 4 as follows:

Table 5 Autocorrelation Test Results

Model Summaryb

\begin{tabular}{|c|c|c|c|c|c|}
\hline Model & $\mathrm{R}$ & R Square & $\begin{array}{l}\text { Adjusted } \quad \mathrm{R} \\
\text { Square }\end{array}$ & Std. Error of the Estimate & Durbin-Watson \\
\hline 1 & $476 a$ & .227 & .200 & 173024.71213 & 1,608 \\
\hline
\end{tabular}

a. Predictors: (Constant), X1, X2

b. Dependent Variable: abs_1

Based on table 4.4 above, the result of Durbin Watson's value is 1,608. with 2 independent variables and the number of samples is 60 , the table value $\mathrm{dL}$ is 1.5144 and du 1.6518 with the $4-\mathrm{du}$ formula, the result is 2.3472 and the Durbin Watson value is 1.608 , which is smaller than $\mathrm{dU}$ so that it can be obtained that there are no problems or symptoms of autocorrelation.

\section{Discussion}

\section{Multiple Linear Regression Analysis}

This analysis is used to determine how much influence the independent variable, namely Mudharabah Revenue Sharing (X1) and Murabahah Margin Income X2) have on the dependent variable, namely Operating Profit (Y). Multiple linear regression analysis is done by setting the equation $=a+b 1 X 1+b 2 X 2+e$, the results of the calculation of the values are as follows:

Table 6 Multiple Linear Regression Test Results

\begin{tabular}{|c|c|c|c|c|c|c|}
\hline \multicolumn{7}{|c|}{ Coefficientsa } \\
\hline \multirow[b]{2}{*}{ Model } & \multicolumn{3}{|c|}{ Unstandardized Coefficients } & $\begin{array}{l}\text { Standardized } \\
\text { Coefficients }\end{array}$ & \multirow{2}{*}{$\mathrm{t}$} & \multirow{2}{*}{ Sig. } \\
\hline & B & & Std. Error & Beta & & \\
\hline \multirow[t]{3}{*}{1} & (Constant) & 5224,907 & 43341,157 & & -121 & .904 \\
\hline & $\mathrm{X} 1$ & .194 & -121 & .181 & 1,596 & .016 \\
\hline & $\mathrm{X} 2$ & .148 & .024 & .697 & 6.147 & .000 \\
\hline
\end{tabular}

a. Dependent Variable: Y

The results of this multiple linear regression equation: $=5524,907+0.194 \mathrm{X} 1+0.148 \mathrm{X} 2+\mathrm{e}$ Which means:

1) The constant value of 5224,907 states that if the independent variables, namely Mudharabah revenue sharing and Murabahah margin income, are zero or fixed, then the total operating profit that occurs is 5524,907

2) The $X 1$ regression coefficient of 0.194 states that if every 1 increase of mudharabah revenue sharing occurs, operating profit will decrease by 0.194

3) The $\mathrm{X} 2$ regression coefficient of 0.148 states that if every 1 increase of murabahah margin income occurs, operating profit will increase by 0.148 


\section{Hypothesis testing \\ F Test (Simultaneous Significance Test)}

This test is intended to determine whether there is an effect of the independent variable together with the dependent variable. This test is also known as the model feasibility test or more popularly referred to as the simultaneous test model. This test identifies the estimated regression model is feasible or not. Appropriate here means that the estimated model is suitable to be used to explain the effect of independent variables on the dependent variable.

The provisions that apply are if the prob value. F count (output results are shown in column sig.) is smaller than the error rate (alpha) of 0.05 (which has been determined) then Ho is rejected or it can be said that the estimated regression model is feasible, whereas if the value of prob. F count is greater than the error rate of 0.05 , then it can be said that $\mathrm{H} 0$ is accepted if the value of $\mathrm{f}$ arithmetic $\mathrm{f}$ table and significance 0.05 .

Table 7 F . Test Results

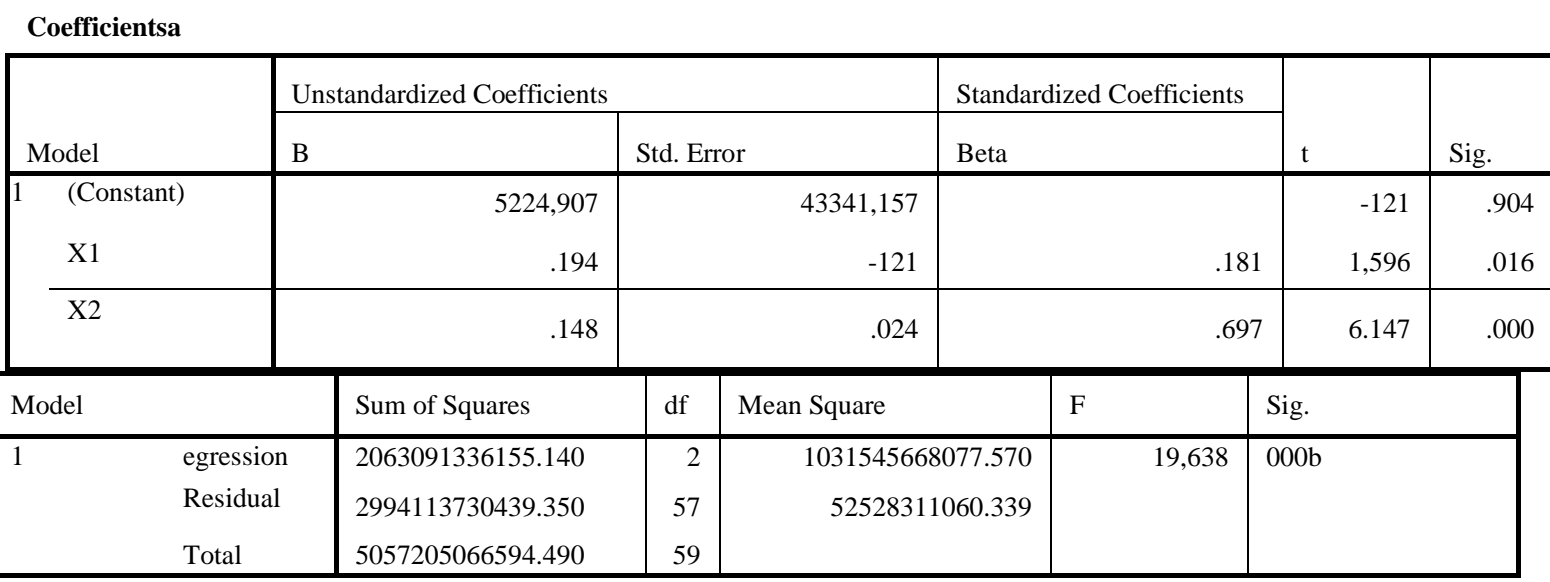

a. Dependent Variable: Y

b. Predictors: (Constant), X1, X2

Based on the table above, the calculated $\mathrm{F}$ value is 19,638 while the Ftable distribution value with an error rate of $5 \%(0.05)$ is 3.15 obtained from table F, with the formula with the formula $\mathrm{df}$ (n1) $=\mathrm{k}-1$ and $\mathrm{df}(\mathrm{n} 2)=\mathrm{n}-\mathrm{k}$, where $\mathrm{df}(\mathrm{n} 1)$ degree of freedom as numerator, $\mathrm{df}(\mathrm{n} 2)$ as denominator, $\mathrm{k}$ (number of variables studied and $\mathrm{n}$ (number of data). This shows that the value of Fcount $19.638>$ Ftable 3.19 and can be indicated by a significant level of $0.000<0.05$ (significant level 5\%), which means that the variables of mudharabah profit sharing and murabahah margin income together have a positive and significant effect on operating profit (Y)

\section{T Test (Partial Significance Test)}

$\mathrm{T}$ test (t-test) or partial test is used to test the effect of each independent variable on the dependent variable. This test compares the probability with a significant level of 0.05 while the other way is by comparing the value of Tcount with Ttable. Provisions for drawing conclusions are as follows: $\mathrm{H} 0$ : There is no significant effect of the independent variable on the dependent variable.

$\mathrm{Ha}$ : There is a significant effect of the independent variable on the dependent variable Table 8 T . Test Results

a. The effect of mudharabah profit sharing on operating profit 
The calculated $t$ value is 1,596 with a probability of 0.016 which is smaller than 0.05 . while the result of $\mathrm{t}$ arithmetic $1.596>0.67860$ is shown by the formula $\mathrm{df}=\mathrm{n}-\mathrm{k}(\mathrm{df}=60-2)$ and constant $=5 \%(0.05)$. Thus, the effect of the regression coefficient on revenue sharing for mudharabah on operating profit is significant.

b. The effect of murabahah margin income on operating profit

The calculated $t$ value is 6,147 with a probability of 0.000 which is smaller than 0.05 . while the result of $\mathrm{t}$-count $6.147>0.67860$ is shown by the formula $\mathrm{df}=\mathrm{n}-\mathrm{k}(\mathrm{df}=60-2)$ and constant $=5 \%(0.05)$.

Thus, the effect of the regression coefficient on the income of the murabaha margin on operating profit is significant.

\section{Discussion of Research Results}

The test in this study uses a multiple linear regression model using the t-test to prove whether there is a significant effect between each variable of mudharabah revenue sharing and murabahah margin income on operating profit at Islamic banks in Indonesia during the 2015-2019 period. While the $\mathrm{F}$ test aims to test whether there is a simultaneous influence between the variables of mudharabah profit sharing and murabahah margin income on operating profits at Islamic banks in Indonesia during the 2015-2019 period. In processing the data, the researcher uses the SPSS 22.0 For Windows application, the objectives to be presented in this study are:

\section{The influence of mudharabah profit sharing has an effect on operating profit in Islamic Banks in Indonesia during the period 2015-2019}

Based on the results of data analysis and hypothesis testing carried out by the authors in this study, it shows that, the revenue sharing of Mudharabah in this study has a positive and insignificant effect on operating profit. Based on the tests conducted, it shows that the revenue sharing of Mudharabah has increased, the operating profit will decrease. This has been proven by the results of hypothesis testing with the probability value of Mudharabah revenue sharing of 1.596 which is greater than $\mathrm{t}$ table 0.67860 with a significance of 0.016 .

Mudharabah is a business cooperation contract between two parties where the first party (shahibul maal) provides all (100\%) capital, while the other party becomes the manager. Mudharabah business profits are divided according to the agreement stated in the contract, whereas if the loss is borne by the owner of the capital if the loss isnot due to negligence of the manager. If the loss is caused by fraud or negligence of the manager, the manager must be responsible for the loss.

Mudharabah financing will increase the costs incurred by financial institutions so that the profits obtained may not be as expected. The revenue generated by Islamic Banks from the distribution of Mudharabah financing may still not be optimally obtained from the distribution of Mudharabah financing. It is still not able to optimize the ability of Islamic Banks to generate profits and does not mean that they do not generate profits at all, only low.

This research is supported by research conducted by Mulyaningsih (2018) in his research on the effect of mudharabah profit sharing on operating profits obtained by the Indonesian Islamic State Bank for the 2014-2016 period. The results show that mudharabah income has a positive and insignificant effect, this is because mudharabah financing will increase the costs incurred by the bank, causing the profits obtained may not be as expected, but that does not mean that this mudharabah income does not generate operating profit, it's just that less than optimal.

\section{The influence of Murabahah margin income has an effect on operating profit at Islamic Banks in Indonesia during the 2015-2019 period}

Based on the results of data analysis and hypothesis testing conducted by the authors in this study, it shows that, Murabahah margin income in this study has a positive and insignificant effect on 
operating profit. Based on the tests conducted, it shows that the revenue sharing of Mudharabah has increased, the operating profit will decrease. This has been proven by the results of hypothesis testing with the probability value of Mudharabah revenue sharing of 6147 which is greater than $t$ table which is 0.67860 with a significance of 0.000

Murabahah is a sale and purchase contract for certain goods, where the seller mentions the selling price which consists of the cost of goods and a certain level of profit for the goods, where the selling price is approved by the buyer. Almost the same term also states that murabahah in terms is selling an item at a capital price plus a profit.

The results of this study are supported by research conducted by Endah Paramita (2017) which states that murabahah margin income has no significant effect on operating profit. In this case, banks should further improve the basic principles in providing in-depth financing to prospective customers so that banks do not choose the wrong choice in the distribution of funds so that funds distributed to customers can be paid back in accordance with the agreed time period.

\section{The Effect of Mudharabah Revenue Sharing and Murabahah Margin Income on Operating Profits at Islamic Banks in Indonesia during the 2015-2019 period}

From the results of data testing conducted on the correlation coefficient research, a positive relationship is obtained which shows the calculated $F$ value of 19,638 while the distribution value of Ftable with an error rate of $5 \%(0.05)$ is 3.15 obtained from table F, with the formula with the formula $\mathrm{df}(\mathrm{n} 1)=\mathrm{k}-1$ and $\mathrm{df}(\mathrm{n} 2)=\mathrm{n}-\mathrm{k}$, where $\mathrm{df}(\mathrm{n} 1)$ degree of freedom as numerator, $\mathrm{df}(\mathrm{n} 2)$ as denominator, $\mathrm{k}$ (number of variables studied and $\mathrm{n}$ (number of data). Fcount 19,638 > Ftable 3.15 and can be shown from a significant level of $0.000<0.05$ (significant level $5 \%$ ), which means that the variables of mudharabah profit sharing and murabahah margin income together have a positive and significant effect on operating profit. .

The results of this study are supported by research conducted by Alfiando (2019) regarding the effect of mudharabah profit sharing and murabahah margin income on corporate profits at PT Bank Syariah Bukopin for the period 2013-2016 a significant effect on company profits.

\section{CLOSING}

Conclusion

Based on the results of the analysis and discussion regarding the revenue sharing of mudharabah and murabahah margin income to operating profit, it can be concluded as follows:

1. Partially, mudharabah profit sharing has a positive and significant effect on Operating Profit at Islamic Banks in Indonesia for the 2015-2019 Period

2. Partially, Murabahah Margin income has a positive and significant effect on Operating Profit at Islamic Banks in Indonesia for the 2015-2019 Period

3. Simultaneously, mudharabah profit sharing and Murabahah Margin income have a positive and significant effect on Operating Profit at Islamic Banks in Indonesia for the 2015-2019 Period

\section{Recommendation}

Recommendations based on the conclusions described above, some recommendations for policy making for companies and further researchers are as follows:

1. The bank should be more careful in choosing customers who will cooperate using mudharabah financing and murabaha financing, because the funds disbursed are very large and this financing has a higher risk than other financing.

2. It is necessary to optimize the strategy carried out by Islamic banks in Indonesia in increasing bank profitability so as to increase revenue and profitability for Islamic banks in Indonesia. 
3. For researchers who will examine the revenue sharing of mudharabah financing and murabahah margin income, the researcher suggests doing research with the following factors:other factors that can influence both external and internal factors. In addition, multiply reading sources or literature related to the title of the research concerned so that the research results will be stronger with more supporting theories.

\section{LITERATURE}

Abdullah Saeed. (2008). Islamic Bank and Interest (Yogyakarta: Student Library)

Abdullah Saeed. (2008). Islamic Bank and Interest (Yogyakarta: Student Library)

Abdul Ghofur Anshori. (2009). Islamic Banking in Indonesia (Yogyakarta: Gadjah Mada University Press, page 132

Adiwarman Azwar Karim. (2003). Islamic Banks, Fiqh and Financial Analysis (Jakarta: The International Of Islamic Thought Indonesia)

Adiwarman Karim. (2016). Islamic Banks, Fiqh and Financial Analysis

Adrian Sutedi. (2009). Islamic Banking (Jakarta: Ghalia Indonesia)

Ahmad Rodoni. (2006). In Muhammad ziqri's Thesis, analysis of the effect of murabahah, mudharabah and musyarakah income on bank profitability

Andri Soemitra. (2009). Islamic Banks and Financial Institutions, Kencana, Jakarta

Sasongko Chess. (2016). Etc., Accounting An Introduction to PSAK (South Jakarta: Salemba Empat)

Harahap, SS (2008). Accounting Theory Jakarta: Rajawali Press.

Heri Sudarsono. (2003). Islamic Banks and Financial Institutions, Edition II, Econisia, Yogyakarta,

Heri Sudarsono. (2015). Islamic Banks and Financial Institutions (Yogyakarta: Ekonisia)

https://www.cnbcindonesia.com/syariah/20180327192123-29-8801/laba-bank-syariah-januari-2018rp-329-miliar-turun-1203. Accessed on 04/09/2020.

https://www.cnbcindonesia.com/market/20200227102428-17-140755/laba-bank-panin-syariahambles-36-di-2019-sahamnya-stagnan. Accessed on 04/09/2020.

Ilham, Rico Nur et all. (2019). Investigation of the Bitcoin Effects on the Country Revenues via Virtual Tax Transactions for Purchasing Management. International Journal of Suplly Management.Volume 8 No.6 December 2019.

Ilham, Rico Nur et all. (2019). Comparative of the Supply Chain and Block Chains to Increase the Country Revenues via Virtual Tax Transactions and Replacing Future of Money. International Journal of Suplly Management.Volume 8 No.5 August 2019.

Ishmael. (2011). Islamic Banking (Jakarta: Kencana Prenada Media Group)

Karim, AA (2004). Islamic Banks: Fiqh and Financial Analysis. Jakarta: RajaGrafindo Persada.

Khatibul Umam. (2009). Islamic Banking, Fundamentals and Dynamics of Its Development in Indonesia

Moh Rifai. (2002). Sharia Banking Concept, CV. Wicaksana, Semarang

Muammar Gaddafi, Arfan Ikhsan, et al., (2018). Business Research Methodology for Thesis, Thesis, and Dissertation. Medan. Madenatera Qualified Publisher.

Muhammad. (2005). "Sharia Concepts and Islamic Bank Products", Short Course Module Islamic Bank, Yogyakarta : Islamic Economic College

Muhammad. (2014). Sharia Bank Fund Management (Jakarta: PT. Rajagrafindo Persada)

Muhammad. (2005). Islamic Bank Financing Management, UPP AMP YKPN, Yogyakarta

Muhammad. (2014). Sharia Financial Management, Fiqh and Financial Analysis (Yogyakarta: UPP STIM YKPN)

Muhammad Syafi'i Antonio. (2001). Sharia Bank From Theory to Practice, Gema Insani Press, Jakarta

Muhammad Syafi'i Antonio. (2001). Islamic Banking From Theory to Practice (Jakarta: Gema Insani Press) 
Naf'an. (2011). Musyarakah and Mudharabah Financing, page 82

Nelson Lam and Peter Lau. (2014). Financial Accounting, IFRS Perspective (South Jakarta: Salemba

Empat)

Mrs. Nurhasanah. (2015). Mudharabah, In Theory and Practice (Bandung: PT. Refika Aditama)

Rachmadi Usman. (2009). Islamic Banking Products and Contracts in Indonesia, PT. Citra Aditya Bakti, Bandung

Rahman Putra. (2013). Introduction to Accounting 1, Accounting Cycle Approach (Jakarta: Erlangga)

Rahman Putra. (2013). Introduction to Accounting 1, Accounting Cycle Approach

Rizal Yaya, Dkk. (2014). Islamic Banking Accounting (South Jakarta : Salemba Empat)

Rusdi Akbar. (2004). Introduction to Accounting (Yogyakarta: UPP AMP YKPN)

Soemarso. (2005). An Introduction to Accounting (Jakarta: Salemba Empat)

Slamet Hartono. (2009). In Muhammad ziqri's Thesis, analysis of the effect of murabahah, mudharabah and musyarakah income on bank profitability

Sri Nurhayati \& Wasilah. (2016). Islamic Accounting in Indonesia (Jakarta: Salemba Empat)

Sugiono. (1999). Business Research Methods (Bandung Alphabeta) 